Bolm Inst. oceanogr., S Paulo, 32(1):71-75, 1983

\title{
INTENSE COASTAL SEDIMENTATION AND EROSION IN THE CANANËIA OUTLET, SOUTHERN STATE OF SÃO PAULO, BRAZIL
}

\author{
Kenitiro SUGUIO ${ }^{1}$ \& Moysēs Gonsalez TESSLER ${ }^{2}$ \\ 1 Instituto de Geociências da Universidade de São Paulo \\ 2 Instituto Oceanográfico da Universidade de São Paulo
}

\section{Synopsis}

The extreme mobility of submerged sand bars at the mouth of the Cananeia outilet has made safe access difficult to the lagoonal region of Cananeia, on the southern coast of the State of São Paulo. This problem is serious enough to have been treated by various authors over the past thirty years. Erosional and depositional processes in the area are the result of the combined, very often conflicting action of tidal currents, waves, and longshore currents that are active in the dispersal of the sand sediments. Thus, at the time that processes of accelerated sedimentation occur at the mouth of the outlet, intensive erosional phenomena act upon neighboring salient features of the coastline, such as Ponta do Perigo on Ilha do Cardoso and Ponta da Trincheira on Ilha Comprida. Comparative analysis of aerial photographs taken in 2962 and 2973 and of some bathymetric profiles allowed us to evaluate the evolution of the erosional process on the eastern side of Ilha do Cardoso during this period interval and to determine the growth tendency of the sand bars in the Cananeira outlet.

Descriptors: Sedinent transport, Coastal erosion, Sediment-water interface, Cananeia out let (SP). Ouaternary period.

Descritores: Transporte de sedimento. Erosáo das costas, Interface sedimento-äqua, Barra de Cananéia (SP). Periodo quaternärio.

\section{Introduction}

The Cananéia-Iguape lagoonal region on the southern coast of the State of São Paulo (Fig. 1) has a communication with the open sea throughout Icapara outlet, near the town of Iguape, at the north, and Cananéia outlet between the Ilhas do Cardoso and Comprida, at the south.
One of the most emphasized phenomena in the area is related to the extreme instability of the Cananéia outlet and neighboring areas due to intense sedimentation and erosion processes. Depositons of old merchant-ship captains about the hard access to the Cananeia lagoonal area across this outlet are registered since the XIXth century

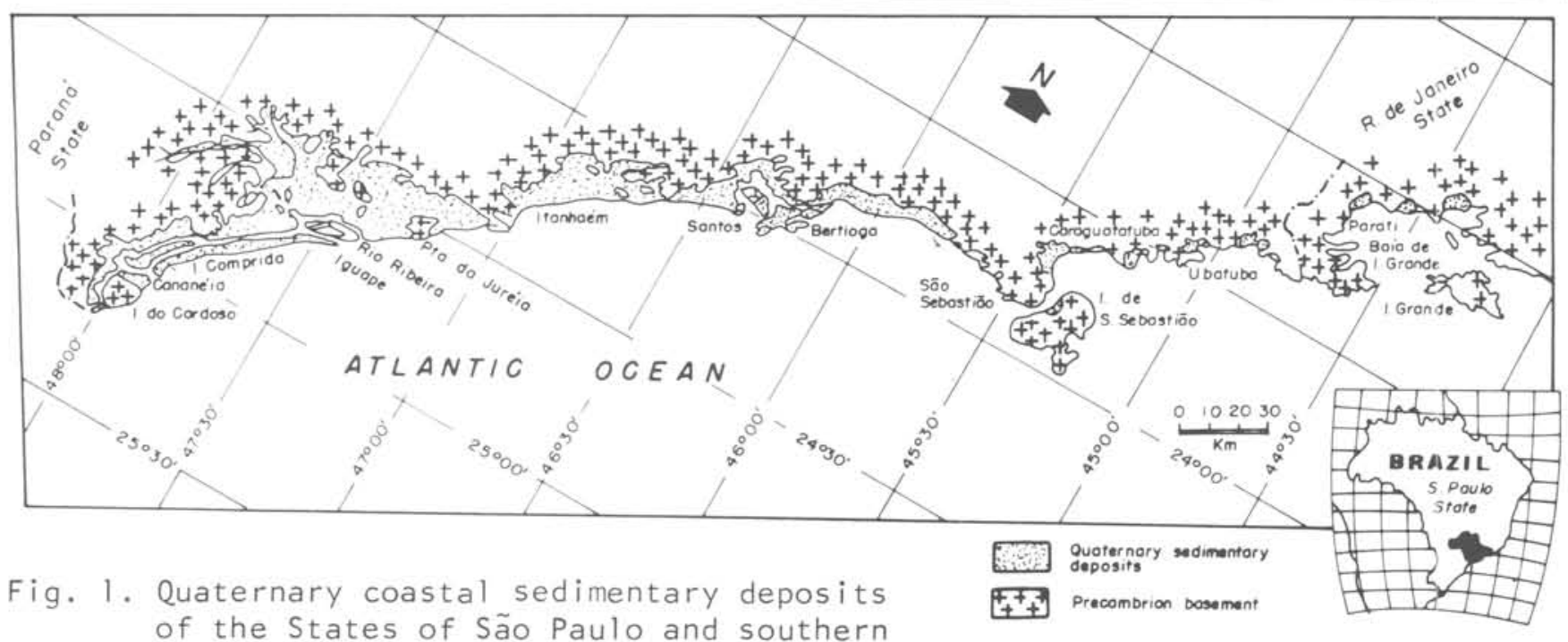
of the States of São Paulo and southern

Publ. n. 584 do Inst. oceanogr. da Usp. Rio de Janeiro (Suguio \& Martin, 1978). 
(GEOBRAs, 1966). This difficulty has been attributed to the extreme mobility of submerged sand bars.

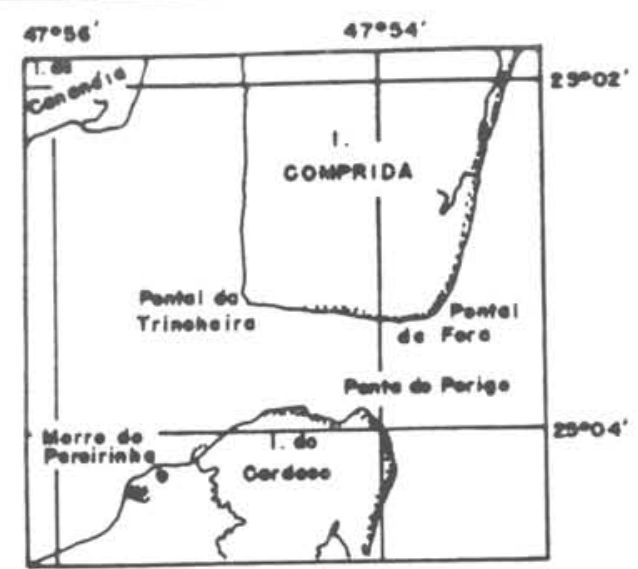

Fig. 2a. Schematic map of the Cananēi a out let region in 1938 (Map n. 1702

- DHN - 1938) (Petri

\& Suguio, 1971)

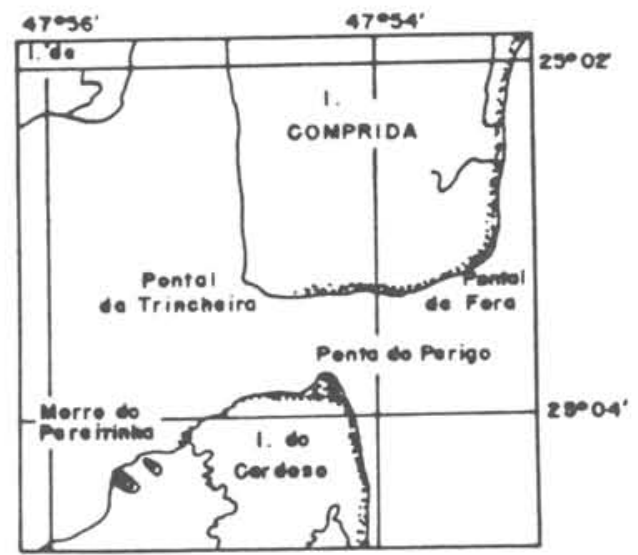

Fig. 2b. Schematic map of the Cananë ia out let region in 1954 - aerial photographs (Petri \& Suguio, 1971).

According to Sadowsky (1954) the eastern edge of the Ilha do Cardoso has been subjected to erosional processes for long time, as a consequence, pushing back continuously westward the Ponta do Perigo. Thus, the southern extremity of the ilha Comprida is being progressively invaded by the sea, influenced by strong winds coming dominantly from the southern quadrant.

Petri \& Suguio (1971) returned to the question using informations from aerial photographs and field surveys (Fig. 2a, b), and as Sadowsky (op. cit.), they admitted a dominance of coastal sedimentation processes though locally winds and tidal currents could rapidly erode less resistent edges of the sandy islands.

\section{Cananéia outlet bathymetric profiles}

Cananéia outlet bathymetric configuration has been interpreted comparing three cruss sections (Fig. 3) based on nautical map of 1938 from Diretoria de Hidrografia e Navegação (Brazilian Navy), and two cross sections based on bathymetric map of 1957 from the Laboratoire National d'Hydraulique Chatou, (France)-(Fig. 4).

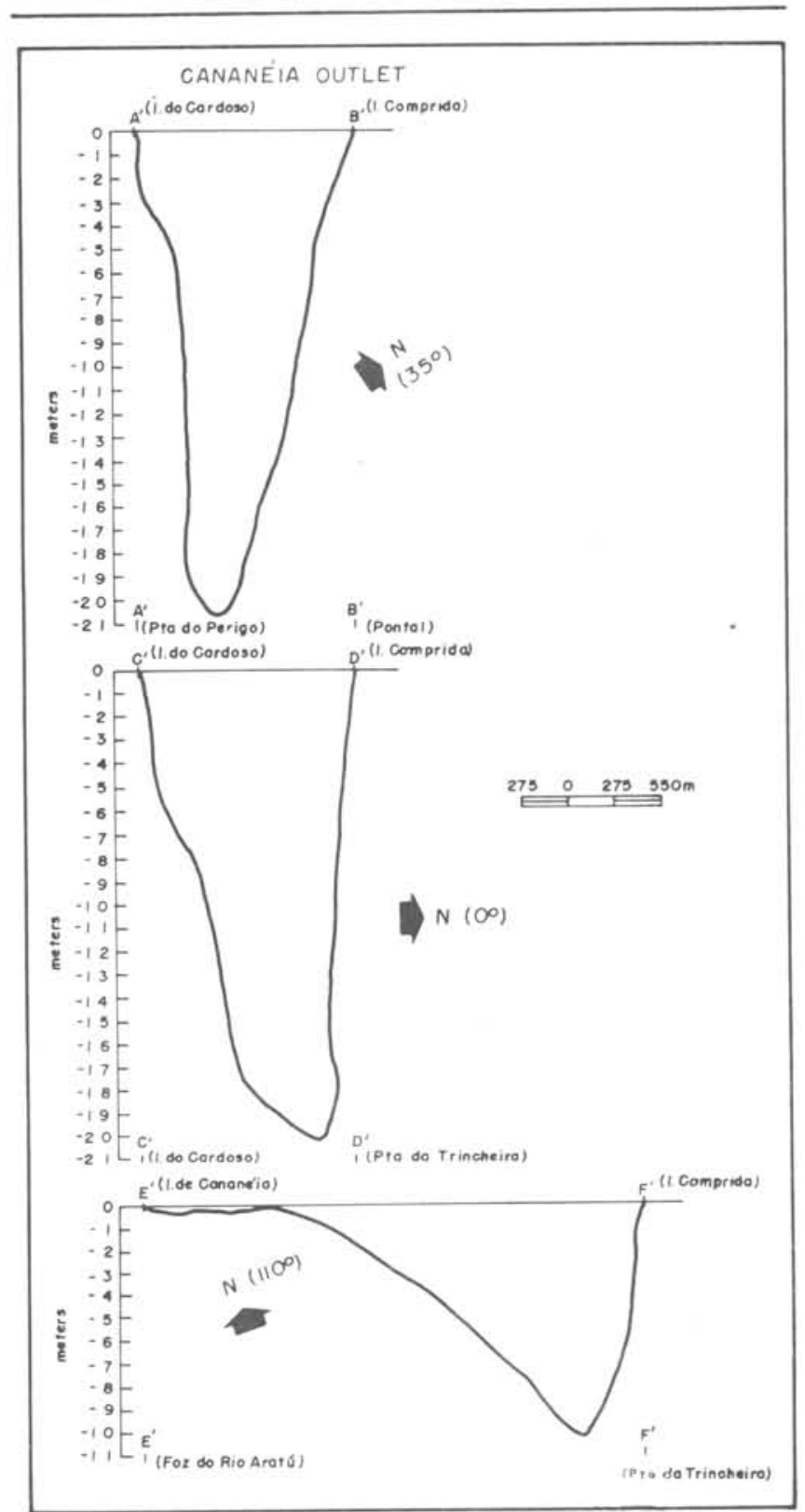

Fig. 3. Bathymetric profiles of the Cananéia out let region (Di retoria de Hidrografia e Navegação, Brazilian Navy, 1938) between i lha Comprida and i lha do Cardoso. 
Two cross sections between ilha do Cardoso and ilha Comprida, both in 1938 as we11 as on 1957 maps, have indicated the occurrence of a circulation channel in the center, whith shallower areas running along the border of the islands. The channel depth has not been practically changed between 1938 and 1957. According to XIXth century documents (GEOBRASs, 1966) this channel has continued unchanged for a still longer time. According to Sadowsky (1952) the Cananéia outlet was about $1,200 \mathrm{~m}$ wide and $20 \mathrm{~m}$ deep.

This circulation channel could be related to paleodrainage valley drowned during the Holocene rising sea-level.

\section{Modifications at the Cananéia outlet}

The aerial photographs taken in 1973 were analysed stereoscopically (Fig. 5) in comparison with the Petri \& Suguio's (1971) surveys (Figs 2a, b). This comparative study showed very striking differences. The eastern edge of ilha do Cardoso acquired a northwestern trend and its extension is passing at western side of Ponta da Trincheira. An aureola of submerged sand bars at the Cananeia outlet, visible in 1973 aerial photographs, could be related to the sediments eroded from the eastern edge of itha do Cardoso.

Northeastward longshore currents must be assumed according to previous works on ilha Comprida (Barcelos et al., 1976, Suguio \& Martin, 1978) which have demonstrated a former lengthening phase and a latter widening episode during the past 3,500 years for the formation of this barrier island.

Sadowsky (1952; 1954) followed the growth of a sandy island near ilha do Cardoso, which indicated that the source area of the sediments was situated at SSW.

The interaction between the wave generated longshore currents and tidal currents gives rise to circulation of great water masses across the Cananeiia outlet. The occurrence of the aureola of submerged sand bars in the Cananéia outlet must be related to this complicated pattern of water masses circulation in the area. The mobility of these sand bars could be related to local hydrodynamic processes.
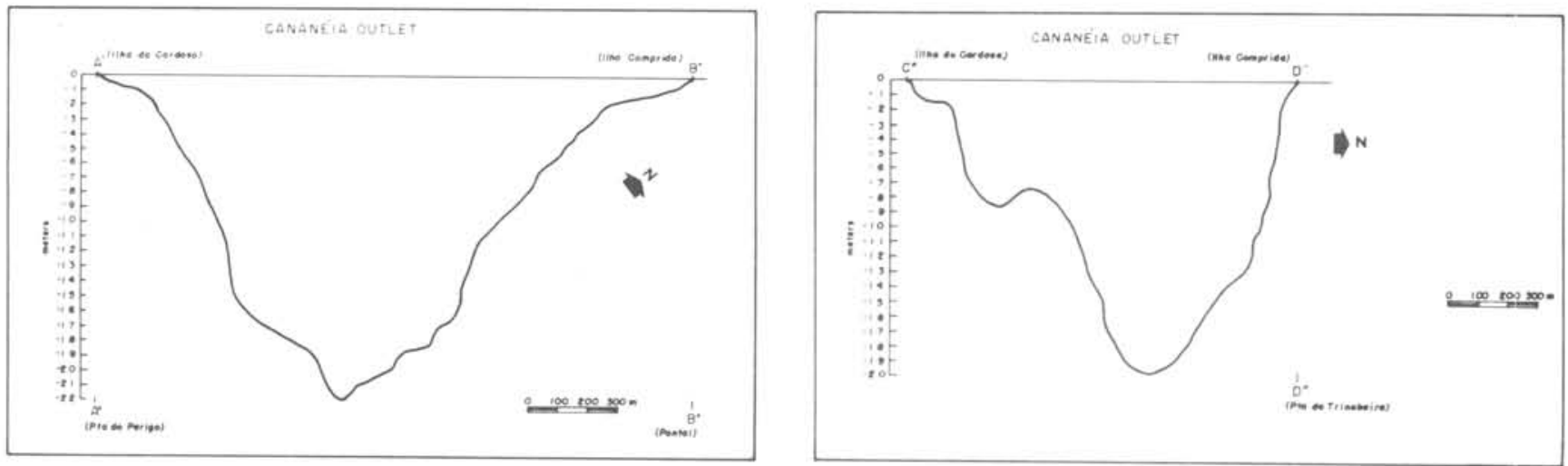

Fig. 4. Bathymetric profiles of the Cananëia outlet region between ilha Comprida and ilha do Cardoso (Laboratoire National d'Hydraulique Chatou and Departamento de Aguas e Energia Elētrica, 1957). 


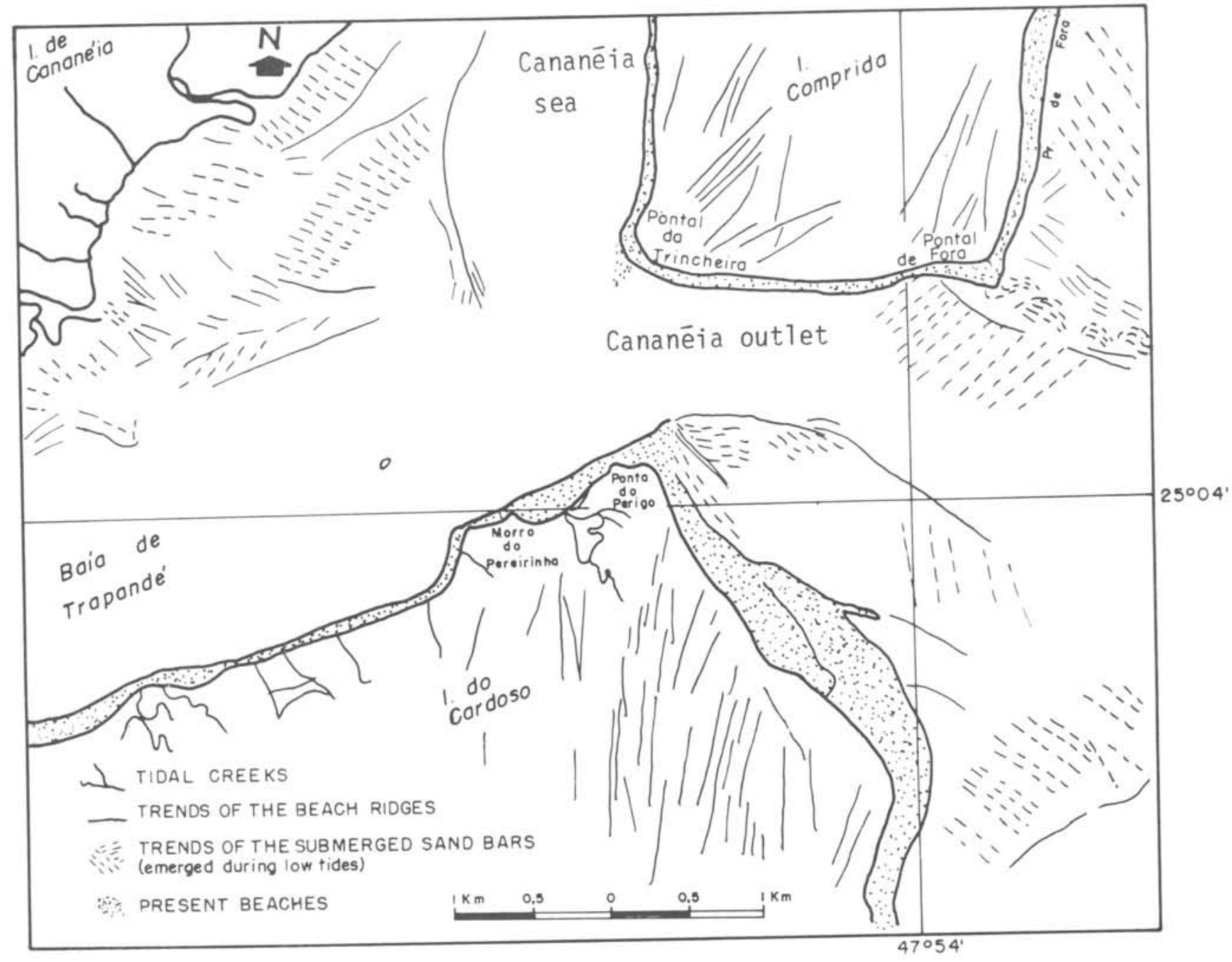

Fig. 5. Schematic map of the Cananéia outlet region according to aerial photographs taken in 1973.

\section{Conclusions}

The comparison of the maps and aerial photographs taken in different years has demonstrated that the eastern edge of Ilha do Cardoso is being subjected to a strong erosion processes due to longshore currents coming from the southeast.

The interaction of the tidal currents and longshore currents is responsible for the sedimentation of submerged sand bars whose mobility could be related to local hydrodynamic processes.

This type of water covered coastal area seems to be maintained within an equilibrium profile so that the sediments are accumulated until a maximum aggradation level over which they could be eroded and reworked being their products transported to other depocenters.

\section{Resumo}

A Barra de acesso à região lagunar de Cananéia-Iguape, na sua porção mais ao sul (Barra de Cananéia), possui bancos arenosos submersos, que através dos tempos tem apresentado extrema mobilidade, dificultando, assim, o acesso de embarcações a essa região.

Processos erosivos e deposicionais atuantes nas regiões vizinhas à Barra, conjugadas às ações conflitantes das correntes de marés, ondas e correntes de deriva litorâneas, ocasionam a ativa dispersão dos sedimentos arenosos.

A anālise comparativa de fotografias aéreas obtidas em 1962 e 1973 permitiu avaliar as tendências erosivas e deposicionais das margens da Barra de Cananéia, bem como a tendência de crescimento dos bancos arenosos submersos. 


\section{References}

BARCELOS, J. H.; SUGUIO, K. \& COIMBRA, A. M. 1976. Sedimentação e sub-ambientes deposicionais de Ilha Comprida, São Paulo. XXIX Congresso Brasileiro de Geologia, Anais v. 2,:107135, Ouro Preto, MG.

DIRETORIA DE HIDROGRAFIA E NAVEGAÇÃO. 1938. Carta no 1702 (Escala 1:27.500), Rio de Janeiro.

GEOBRĀS S/A. 1966. Complexo Valo Grande, Mar Pequeno e Rio Ribeira de Iguape. Relatơrio Geobrās S/A, Engenharia e Fundações para o Serviço do Vale do Ribeira, Departamento de Aguas e Energia Elétrica do Estado de São Paulo, 2 v.

LABORATOIRE NATIONAL D'HYDRAULIQUE CHATOU. 1957. Levantamento batimétrico da barra de Cananéia, Estado de São Paulo. Mapa batimétrico 1:10.000. Relatório do Departamento de Agguas e Energia Elétrica do Estado de São Paulo.
PETRI, S. \& SUGUIO, K. 1971. Exemplo do trabalho de mar no litoral sul do Brasil. Notic. geomorfol., 11(21): 61-66.

SADOWSKY, V. 1952. Observações sobre as modificações em curso na entrada de Cananéia, de sua barra e da região adjacente. I. Desgaste das costas. no 1. Ponta da Trincheira (1952). Bolm Inst. oceanogr., S Paulo, 3(1/2): 201-212.

1954. Novas contribuiao estudo da entrada da barra de Cananéia. Bolm Inst. oceanogr., S Paulo, 4(1/2):151-177.

SUGUIO, K. \& MARTIN, L. 1978。 Quaternary marine formations of the State of São Paulo and southern Rio de Janeiro. Spec. Publ. Intern. Symp. Coastal Evolut. Quaternary, S Paulo, (1) $: 1-55$.

(Received 07-0ct-1982; accepted 18-Apr-1983) 